\title{
ТЕХНОЛОГІЧНІ СХЕМИ ГЕОТЕС НА ГЕОТЕРМАЛЬНИХ РОДОВИЩАХ 3 АНОМАЛЬНО ВИСОКИМ ПЛАСТОВИМ ТИСКОМ
}

\author{
Ю.П. Морозов ${ }^{1}$, С.В. Дубовський ${ }^{2}$ \\ ${ }^{1}$ Інститут відновлюваної енергетики НАН України, \\ 02094, вул. Г. Хоткевича, 20А, м. Київ, Україна. \\ ${ }^{2}$ Інститут технічної теплофізики НАН України, \\ 03057, вул. М. Капніст, 2А, м. Київ, Україна.
}

Представлені результати термодинамічного та гідравлічного моделювання технологічних варіантів виробництва електричної енергії в геотермальному ииркуляційному контурі з використанням теплової, механічної та хімічної енергії флюїду геотермальних родовищ з аномально високим пластовим тиском (АВПТ). Геотермальні поклади такого типу зустрічаються на глибинах до 4000 м і характеризуються позитивною температурною аномалією, що визначає перспективність їх використання у геотермальній енергетиці. Однак використання покладів АВПТ ускладнює високий тиск флюїду на поверхні, щзо зумовлює підвищену металоємність наземного обладнання та потенційну небезпеку для оточення внаслідок можливої розгерметизаиії. Які базову модель прийнято бінарну ГеоТЕС на органічному ичиклі Рєнкіна під повним тиском геотермального флюїду. Заразом, з метою зниження металоємності та попередження наслідків аварійних ситуацій, розглянуто технологічні схеми ГеоТЕС з попереднім зниженням тиску за допомогою турбіни Пелтона із відділенням та використанням розчиненого метану для виробництва електричної й теплової енергї у газопориневій когенераційній установиі. Порівняльні розрахунки технологічних схем проводились за даними геотермального родовища АВПТ Мостицька, Україна, з температурою до $140{ }^{\circ} \mathrm{C}$, пластовим тиском 500 бар і вмістом розчиненого метану $1 \mathrm{M}^{3} / \mathrm{M}^{3}$ на глибині $3600 \mathrm{M}$. Наведено результати математичного моделювання гідродинаміки та теплообміну руху флюїду в свердловинах, процесів зниження тиску в турбіні Пелтона, видалення та використання розчиненого метану в когенераційній установиі, термодинамічного розрахунку паротурбінного ичиклу ГеоТЕС, які дозволили провести порівняння базового й альтернативних варіантів технологічних схем за рівнем електричної й теплової потужності. Одержані дані призначені для подальшого використання у техніко-економічному зіставленні розглянутих технологічних схем. Бібл. 10, табл. 6., рис. 4.

Ключові слова: геотермальна енергетика, геотермальна свердловина, аномально високий пластовий тиск, турбіна Пелтона, органічний ичикл Ренкіна.

\section{TECHNOLOGICAL SCHEMES OF GEOTPP ON GEOTHERMAL DEPOSITS WITH ABNOMALLY HIGH LAYER PRESSURE}

\author{
Yu. Morozovi ${ }^{1}$ S. Dubovskyi² \\ ${ }^{1}$ Institute of renewable energy of NAS of Ukraine, \\ 02094, 20A, G. Khotkevycha St., Kyiv, Ukraine. \\ ${ }^{2}$ Institute of Engineering Thermophysics of NAS of Ukraine, \\ 03057, 2A, M. Kapnist St., Kyiv, Ukraine.
}

The results of thermodynamic and hydraulic modeling technological variants of power and heat production by using in the geothermal circulation circuit using thermal, mechanical and chemical energy of the fluid of geothermal deposits with abnormally high formation pressure (AHFP) are presented. Geothermal deposits of this type are found at depths up to $4000 \mathrm{~m}$ and are characterized by a positive temperature anomaly, which determines the prospects for their use in geothermal energy. However, the use of AHFP deposits is complicated by the high fluid pressure on the surface, which leads to increased metal content of ground equipment and potential danger to the environment due to possible depressurization. The binary GeoTPP on the Rankine organic cycle under full pressure of geothermal fluid is accepted as the basic model. In addition, in order to reduce metal consumption and prevent the consequences of emergencies, GeoTPP technological schemes with preliminary pressure reduction using a Pelton turbine with separation and use of dissolved methane for electricity and heat production in a gas-piston cogeneration unit are considered. Comparative calculations of technological schemes were performed according to the AHFP geothermal field Mostytska, Ukraine with temperature up to $140^{\circ} \mathrm{C}$, formation pressure over 500 bar and dissolved methane content $1 \mathrm{~m}^{3} / \mathrm{m}^{3}$ at a depth of $3600 \mathrm{~m}$. The results of mathematical modeling of hydrodynamics and heat transfer of fluid motion in wells, processes of pressure reduction in Pelton turbine, removal and use of dissolved methane in cogeneration unit, thermodynamic calculation of geothermal steam turbine cycle are presented, which allowed (C) Ю.П. Морозов, С.В. Дубовський, 2021 Відновлювана енергетика. 2021. № 2 
comparing the basic and alternative versions of technological schemes for the level of electric and thermal power. The obtained data are intended for further use in the technical and economic comparison of the considered technological schemes. Ref. 10, table 6, fig.4. Keywords: geothermal energy, geothermal well, abnormally high formation pressure, Pelton turbine, organic Rankin cycle.

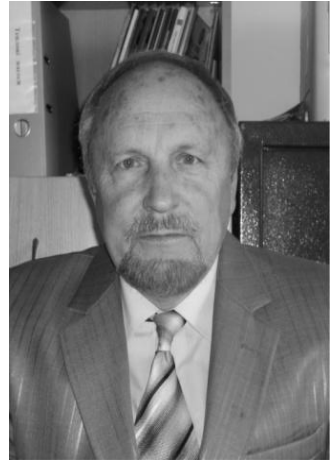

Ю.П. Морозов Yu. Morozov

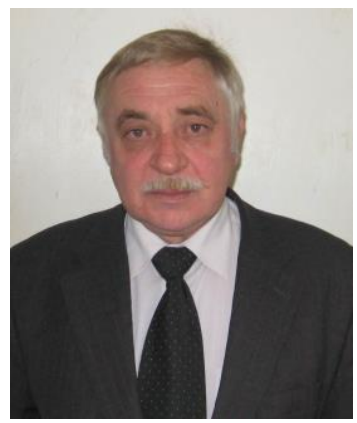

C.В. Дубовський S. Dubovskyi
Відомості про автора: зав. відділу геотермальної енергетики Інституту відновлюваної енергетики НАН України, доктор технічних наук, старший науковий співробітник

Освіта: Національний технічний університет України «Київський політехнічний інститут імені Ігоря Сікорського»

Наукова сфера: відновлювана енергетика, геотермальна енергетика, використання тепла довкілля

Публікації: більше 190

ORCID: 0000-0003-1632-9735

Контакти: тел./факс: +38 (044) 206-28-09

e-mail: geotherm@ukr.net

Відомості про автора: провідний науковий співробітник відділу теплофізичних основ енергоощадних технологій Інституту технічної теплофізики НАН України, доктор технічних наук, старший науковий співробітник

Освіта: Московський енергетичний інститут. Інженер-теплоенергетик Наукова сфера: Енергетичні системи i комплекси, термодинамічний аналіз та моделювання теплоенергетичних установок i систем перетворення енергії, когенерація, теплові насоси, енергоефективність Публікації: Більше 200 друкованих праць, 4 монографіі

ORCID:0000-0001-9418-2092

Контакти: тел.:+38(067)587-67-81

e-mail: $\underline{\text { s.w.dubovskoy@gmail.com }}$
Author information: Head of the Department of Geothermal Energy of the Institute of Renewable Energy of the National Academy of Sciences of Ukraine, doctor of technical sciences, senior researcher

Education: National Technical University of Ukraine "Igor Sikorsky Kyiv Polytechnic Institute"

Research area: renewable energy, geothermal energy, use of warm environment.

Publications: more than 190

ORCID: 0000-0003-1632-9735

Contacts: phone/fax: +38 (044) 206-28-09

e-mail: geotherm@ukr.net

Author information: leading Researcher of the Department of Thermophysical Foundations of Energy Saving Technologies

Education: Moscow Power Engineering Institute Heat power engineer

Research area: Thermodynamic analysis and modeling of thermal power units and energy conversion systems.Cogeneration, heat pumps, energy efficiency

Publications: more than 200 publications, 4 monographs

ORCID: 0000-0001-9418-2092

Contacts: phone: +38(067)587-67-81

e-mail: $\underline{\text { s.w.dubovskoy@gmail.com }}$

\section{Перелік використаних позначень та скорочень:}

Н - глибина свердловин, м;

$\alpha$ - коефіцієнт тепловіддачі від флюїду до стінки обсадної труби, Вт/м² К;

$\lambda_{1}$ - коефіцієнт теплопровідності стінки свердловини;

$\mathrm{D}$ - зовнішній діаметр обсадної труби, м;

$d$ - внутрішній діаметр свердловини, м;

$\lambda_{2}, a_{2}-$ коефіцієнт теплопровідності та температуропровідності породи;

$F_{o}=\mathrm{a}_{2} \frac{t}{D^{2}} .-$ критерій Фурьє;

$\mathrm{w}$ - середня швидкість води у свердловинах, м/c;

$\mathrm{a}, \lambda_{1}, v, c_{v}, \rho$-коефіцієнт теплопровідності;

температуропровідності, кінематичної в'язкості, ізохорна теплоємність та густина води;

$\mathrm{Re}=\frac{\mathrm{wd}}{\mathrm{v}}-$ число Рейдольдса;

$\operatorname{Pr}$ - критерій Прандтля;

$\mathrm{Nu}$ - число Нусельта; $p_{o}, p_{1}, p_{2}-$ статичний тиск води у пласті та на гирлі видобувної та закачувальної свердловин, відповідно; $T_{o}, T_{1}, T_{2}, T_{3}$ - температура води на вибої та гирлі видобувної свердловини, на гирлі та вибої закачувальної свердловини, відповідно; $U_{o}, U_{l}$ - температура породи в пласті та на поверхні, відповідно;

$p_{1}, p_{2}$ - статичний тиск на гирлі видобувної та закачувальної свердловин, відповідно;

ГеоТЕС - геотермальна теплова електрична станція; ГПУ - газопоршнева установка;

ГЦК - геотермальний циркуляційний контур;

ЖЕН - живильний електронасос;

ККД - коефіцієнт корисної дії;

ПТУ - паротурбінна установка;

ЦН - циркуляційний насос системи охолодження

ГеoTEC. 
Вступ. Аномально високим пластовим тиском (АВПТ) у покладах води, нафти й газу прийнято вважати тиск, який помітно - у півторадва рази й більше - перевищує умовний гідростатичний тиск, що чинить стовп прісної води, рівний за висотою глибині покладу, рахуючи від поверхні родовища. Геологічні зони 3 АВПТ часто супроводжуються позитивною температурною аномалією, а отже, являють інтерес для геотермальної енергетики [1]. Один 3 таких покладів геотермальної води під АВПТ в Україні виявлений за даними буріння пошуковорозвідувальних свердловин на геотермальній площі Мостиська. Тиск води цього родовища на глибині 3660 м становить 525 бар, розрахункова пластова температура вище $130{ }^{\circ} \mathrm{C}$, інтервал продуктивної підземної зони - 3610-3660 м [2].

Відомо, що для перетворення теплової енергії флюїду з відповідною температурою на електричну енергію традиційно використовують бінарні ГеоТЕС на органічному циклі Рєнкіна (ORC), які виключають потрапляння в оточуюче середовище шкідливих компонентів геотермального флюїду [3]. Однак високий тиск флюїду на поверхні, що може сягати 150 бар і вище, диктує необхідність використання товстостінного теплообмінного обладнання, трубопроводів та арматури, що істотно збільшує капітальні витрати на спорудження ГеоТЕС. Крім того, видобуток геотермального флюїду з АВПТ нерідко супроводжується пульсаціями тиску [1], які несуть загрозу розгерметизації наземного обладнання з забрудненням довкілля.

У зв'язку 3 цим поряд 3 традиційною можуть розглядатися й інші технологічні схеми використання геотермальних покладів з АВПТ, які передбачають зниження тиску флюїду перед його використанням у циклі ГеоТЕС із повторним збільшенням перед закачуванням у пласт. Редукування i повторне збільшення тиску геотермальної води неминуче знижує ефективність виробництва електричної енергії, однак цей недолік певною мірою компенсують менші витрати на наземне обладнання. Водночас редукція тиску геотермальної води дозволяє вилучити й використати у циклі ГеоТЕС газоподібні вуглеводні, які нерідко присутні у пластовій воді під АВПТ у розчиненому вигляді, що також дає можливість збільшити електричну потужність ГеоТЕС.

Постановка завдань. Основна мета роботи полягає у визначенні й порівнянні технічних характеристик можливих технологічних схем використання геотермальної води покладів 3 АВПТ для виробництва електричної енергії на основі теплових і гідравлічних розрахунків. Для цього необхідно виконати такі завдання:

1. Розробити раціональні технологічні схеми та зробити аналіз технологічних обмежень на використання геотермальної води покладів під АВПТ для виробництва електричної й теплової енергії 3 застосуванням зниження тиску геотермального флюїду та вилученням розчинених горючих вуглеводнів та без них.

2. Визначити на основі теплових i гідравлічних розрахунків технічні параметри розроблених схемних рішень, необхідних для подальшого проведення техніко-економічних порівнянь.

Викладення основного матеріалу. Робочий тиск є одним з основних факторів, що суттєво впливають на металоємність i, відповідно, вартісні показники енергетичного обладнання. Кількісне уявлення щодо цього можна одержати 3 рис. 1, на якому наведена залежність маси стандартних сталевих виробів (трубопроводів та арматури) різного умовного діаметру (DN) від рівня робочого тиску за даними [4]. Як можна бачити, підвищення внутрішнього тиску від 10 до 100-130 бар дається ціною зростання металоємності обладнання, а відповідно й вартості трубопроводів, арматури й теплообмінних поверхонь ГеоТЕС на боці флюїду в 4-5 разів. 


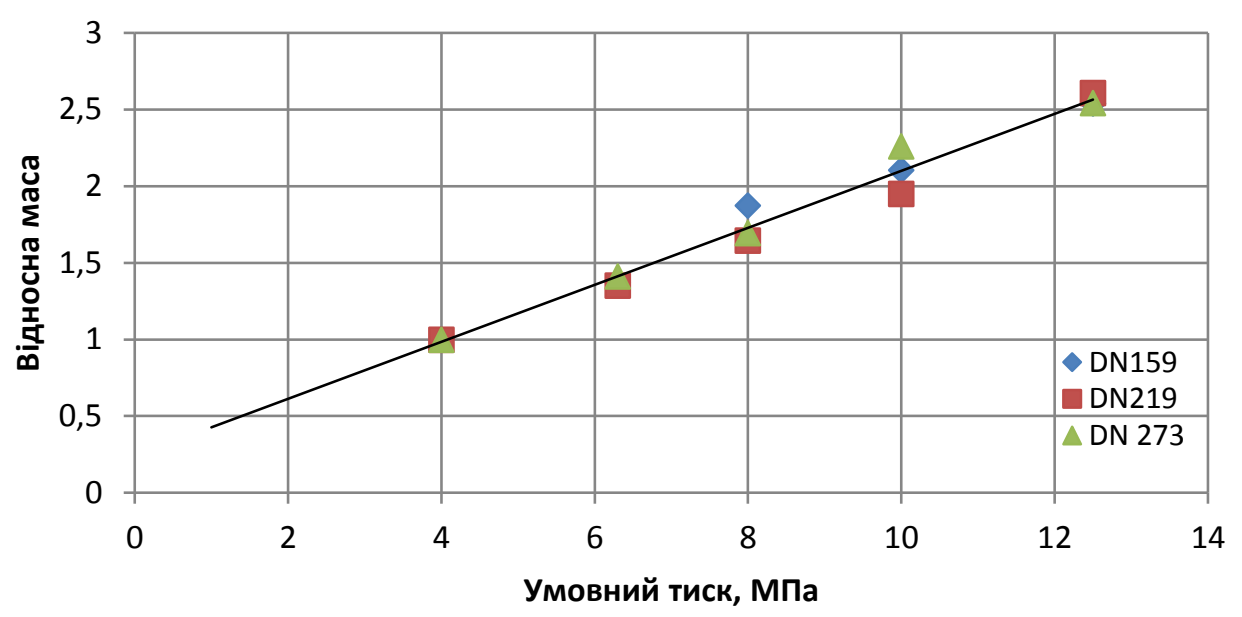

Рис. 1. Залежність маси трубопровідної арматури від рівня робочого тиску [4]

Fig. 1. Weight of pipeline fittings depending on the working pressure level [4]

Зниження тиску флюїду 3 мінімальними втратами енергії можливе на основі технології адіабатного (миттєвого) скипання (single flesh); гідропарових турбін; гідротурбін Пелтона [5].

Найпростіше було б використати гідропарові турбіни, можливість створення яких задеклароване у [6], а використання на ГеоТЕС у [7]. Однак ця технологія ще не набула рівня промислових зразків і ії властивості достеменно не відомі.

Технологія адіабатного скипання орієнтована на використання парових турбін на водяній парі, що утворюється в результаті миттєвого зниження тиску геотермальної води [1]. Ефективне використання цієї технології має місце за температури геотермальної води понад $180{ }^{\circ} \mathrm{C}$, нижче якої парова турбіна буде перебувати під вакуумом. Це ускладнює конструкцію ущільнень, спричиняє зниження ефективності парових турбін та зростання їх масогабаритних показників.

3 огляду на це у даній роботі основну увагу приділено технологічним схемам, що передбачають редукування води в гідротурбіні Пелтона 3 iї наступним використанням у бінарній ГеоТЕС на органічному циклі Рєнкіна. Якщо флюїд містить помітну кількість розчиненого метану, редукування тиску доповнюється дегазацією води з видобутком горючих газів та їх використанням для виробництва електричної й теплової енергії в когенераційній установці.

Базовий варіант спорудження ГеоТЕС. Як базову розглянуто традиційну технологічну схему бінарної ГеоТЕС під повним тиском геотермальної води (рис. 2).

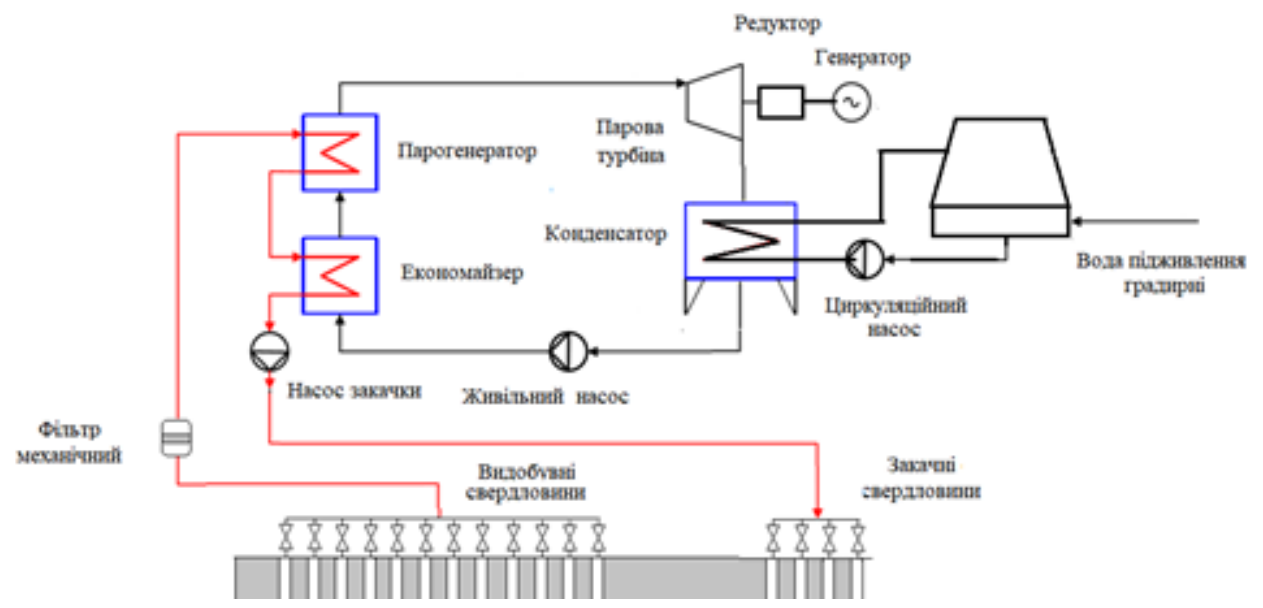

Рис. 2. Спрощена схема бінарної ГеоТЕС без редукування надлишкового тиску

Fig. 2. Simplified scheme of binary GeoTES without reduction of excess pressure 
Економайзер та парогенератор, наведені на схемі, насправді об'єднані в єдиний теплообмінний апарат поверхневого типу геотермальний теплообмінник, функцією якого $є$ передача теплоти у герметичний контур циркуляції робочого тіла паротурбінної установки. Як робоче тіло може використовуватися і знесолена вода, й органічні речовини - хладони. Основною перевагою хладонів $є$ можливість підтримки надлишкового тиску (відносно атмосферного) у всіх точках паротурбінного циклу, а також значно менші, ніж для води, питомі об'єми пари, що визначає більшу компактність парових турбін.

Тепловий $\mathrm{i}$ гідравлічний розрахунок свердловин ГЦК. Температура і тиск флюїду на гирлі видобувної свердловини, як і тиск на гирлі свердловини закачування, визначалися на підставі теплового й гідравлічного розрахунку течії флюїду з урахуванням плинності умов теплової взаємодії з оточуючими гірськими породами у часі на основі аналітичної моделі [8], що традиційно використовується в інженерних розрахунках у нафтогазовій галузі. У цій роботі в зазначеній моделі додатково враховуваний ефект виділення теплоти внаслідок гідравлічних втрат, що дозволило одержати наведені нижче формули для розрахунку температур геотермальної води у характерних точках ГЦК.

Температура на гирлі видобувної свердловини:

$$
T_{1}=\mathrm{U}_{1}+\left(\theta+T_{\mathrm{o}}-\mathrm{U}_{1}\right) \cdot \frac{1-\exp (-\mathrm{m})}{\mathrm{m}}
$$

$$
\text { Температура води свердловини }
$$

закачування, що повертається у пласт:

$$
\begin{gathered}
T_{3}=T_{2}+\left(\theta+m \mathrm{U}_{1}-\left(\mathrm{U}_{\mathrm{o}}-\right.\right. \\
\left.\left.-\mathrm{U}_{1}\right)\right) \frac{1-\exp (-\mathrm{m})}{m}+\left(\mathrm{U}_{\mathrm{o}}-\mathrm{U}_{1}\right),
\end{gathered}
$$

де $\theta=\sigma \frac{\mathrm{w}^{2}}{2 \mathrm{c}_{\mathrm{v}}} \cdot \frac{\mathrm{H}}{\mathrm{d}}-$ адіабатичний нагрів флюїду внаслідок виділення теплоти тертя, ${ }^{\circ} \mathrm{C}$;

$\mathrm{m}=\frac{\mathrm{KH}}{\mathrm{Gc}_{\mathrm{v}}}, \quad K=\frac{2 \pi}{\frac{2}{\alpha d}+\frac{\operatorname{Ln}\left(\frac{D}{d}\right)}{\lambda 1}+\frac{\operatorname{Ln}\left(1+1,635 \sqrt{F_{0}}\right)}{\lambda 2}}-$ коефіцієнт теплопередачі.

Середній коефіцієнт тепловіддачі й коефіцієнт гідравлічної втрати тиску на тертя визначаються за формулами Міхеєва та Нікурадзе для турбулентної течії в круглих трубах: $\alpha=$ $\mathrm{Nu} \frac{\lambda_{1}}{\mathrm{~d}}, \mathrm{Nu}=0,021 \operatorname{Re}^{0,8} \operatorname{Pr}^{0,43}, \sigma=\frac{1}{\left(2 \lg \left(\frac{\mathrm{d}}{\Delta}\right)+1,14\right)^{2}}$.

Ееквівалентна шорсткість $\Delta$ стволів свердловин приймається рівною 0,5 мм. Теплофізичні властивості геотермальної води приймалися за середніми значеннями температури й тиску у відповідних свердловинах. Статичний тиск на поверхні видобувної та закачувальної свердловин визначалися за формулами:

$$
\begin{aligned}
& p_{1}=p_{o}-\Delta p_{\mathrm{T} 1}-\rho_{1} g H, \\
& p_{2}=p_{o}+\Delta p_{\mathrm{T} 2}-\rho_{2} g H .
\end{aligned}
$$

Основні результати розрахунку параметрів флюїду на початку 3-го року експлуатації ГеоТЕС наведено у табл. 1. 
Таблиця 1. Результати термогідравлічного розрахунку видобувної та закачувальної свердловин

Table 1. The results of thermohydraulic calculation of production and injection wells

\begin{tabular}{|c|c|c|c|c|}
\hline \multirow{2}{*}{ Показник } & \multirow{2}{*}{ Познака } & \multirow{2}{*}{ Розм. } & \multicolumn{2}{|c|}{ Свердловина } \\
\hline & & & Видобувна & Закачувальна \\
\hline Середньорічна температура на поверхні & $\mathrm{U}_{1}$ & ${ }^{\circ} \mathrm{C}$ & \multicolumn{2}{|r|}{9} \\
\hline Глибина свердловини & $\mathrm{H}$ & M & \multicolumn{2}{|c|}{3700} \\
\hline Внутрішній діаметр & $\mathrm{d}$ & M & \multicolumn{2}{|r|}{0,2} \\
\hline Зовнішній діаметр & $\mathrm{D}$ & м & \multicolumn{2}{|c|}{0,22} \\
\hline Статичний тиск у пласті & $\mathrm{p}_{\mathrm{o}}$ & бар & \multicolumn{2}{|c|}{500} \\
\hline Температура пласту & $\mathrm{U}_{\mathrm{o}}, \mathrm{T}_{\mathrm{o}}$ & ${ }^{\circ} \mathrm{C}$ & \multicolumn{2}{|c|}{140} \\
\hline Коефіцієнт теплопровідності породи & $\lambda 2$ & $\mathrm{BT} / \mathrm{MK}$ & \multicolumn{2}{|c|}{2,56} \\
\hline Коефіцієнт температуропровідності породи & $\mathrm{a}_{2}$ & $\mathrm{M}^{2} / \mathrm{c}$ & \multicolumn{2}{|c|}{$8,85_{10}^{-07}$} \\
\hline Час з початку експлуатації & $\mathrm{t}$ & років & \multicolumn{2}{|r|}{2} \\
\hline Об’ємна витрата флюїду & $\mathrm{V}$ & $\mathrm{m}^{3} /$ добу & 6000,0 & 5650,1 \\
\hline Масова витрата флюїду & G & кг/с & 65,3 & 65,3 \\
\hline Середня швидкість флюїду & $\mathrm{w}$ & $\mathrm{M} / \mathrm{c}$ & 2,2 & 2,1 \\
\hline Середня густина флюїду & $\rho$ & $\mathrm{M}^{3} / \mathrm{\kappa} \Gamma$ & 939,7 & 997,9 \\
\hline Коефіцієнт гідравлічних втрат на тертя & $\sigma$ & & 0,0247 & 0,0248 \\
\hline Середня температура води у свердловинах & $\mathrm{T}_{\mathrm{mid}}$ & ${ }^{\circ} \mathrm{C}$ & 139,1 & 51,3 \\
\hline $\begin{array}{l}\text { Температура на гирлі видобувної / на вибої } \\
\text { закачувальної свердловин }\end{array}$ & $\mathrm{T}_{1} / \mathrm{T}_{3}$ & ${ }^{\circ} \mathrm{C}$ & 137,3 & $53,7^{1)}$ \\
\hline Гідравлічний опір на тертя & $\Delta \mathrm{p}_{\mathrm{T}}$ & бар & 10,5 & 9,9 \\
\hline Гідростатичний тиск & $\Delta \mathrm{p}_{\mathrm{r}}$ & бар & 340,7 & 361,8 \\
\hline Тиск на поверхні & $\mathrm{p}_{1}, \mathrm{p}_{2}$ & бар & 148,8 & 148,1 \\
\hline
\end{tabular}

При вибраному дебіті різниця тисків на гирлі видобувної та закачувальної свердловин практично відсутня внаслідок компенсації гідравлічних втрат на тертя різницею статичних тисків, що виникає внаслідок температурної залежності густини води у свердловинах. Отже, розрахунковий напір насосу закачування визначається переважно гідравлічними втратами наземного обладнання ГеоТЕС. Температура на гирлі видобувної свердловини неістотно відрізняється від температури пласту через дію двох ефектів: поступового вирівнювання температур флюїду та порід, що оточують свердловину 3 плином часу, та самонагрівання флюїду внаслідок виділення теплоти тертя. Як показують розрахунки, рівноважне значення температури флюїду на поверхні досягається через два роки з початку експлуатації ГеоТЕС.

Вихідні параметри, що прийняті $\mathrm{y}$ тепловому розрахунку паротурбінної установки ГеоТЕС, наведено у табл. 2. 
Таблиця 2. Вихідні параметри бінарної ГеоТЕС

Table 2. Initial parameters of binary GeoTPP

\begin{tabular}{|l|c|c|}
\hline \multicolumn{1}{|c|}{ Показники } & Розм. & Значення \\
\hline Температура флюїду на вході & ${ }^{\circ} \mathrm{C}$ & 136 \\
\hline Тиск флюїду на вході & бар & 148,0 \\
\hline Витрата флюїду & кг/c & 65,0 \\
\hline Робоче тіло & - & $\mathrm{R} 134 \mathrm{a}$ \\
\hline Температура охолоджувальної води & ${ }^{\circ} \mathrm{C}$ & 15 \\
\hline Критичний натиск у парогенераторі & ${ }^{\circ} \mathrm{C}$ & 10 \\
\hline Нагрів у конденсаторі & ${ }^{\circ} \mathrm{C}$ & 9 \\
\hline Натиск у конденсаторі & ${ }^{\circ} \mathrm{C}$ & 8 \\
\hline Внутрішній відносний ККД турбіни & - & 0,85 \\
\hline Електромеханічний КПД турбоагрегату & - & 0,93 \\
\hline Електромеханічний ККД ЖЕН & - & 0,712 \\
\hline Електромеханічний ККД ЦН & - & 0,70 \\
\hline
\end{tabular}

\section{Термодинамічний} паротурбінної установки на органічному робочому тілі проводився за відомою методикою, наведеною, зокрема, у [9] 3 використанням програмного середовища REFPROP. Вихідні параметри робочого циклу ГеоТЕС і результати розрахунку, в яких враховані витрати електричної енергії на власні потреби ПТУ (крім насосу закачування) наведені у табл. 3 залежно від заданої температури пари робочого тіла на вході в турбіну.

розрахунок ристики станції поліпшуються зі зростанням початкової температури випаровування. Однак при цьому зростає вологість пари в кінці процесу розширення у паровій турбіні, що може спричинитися до ерозійного зношення елементів проточної частин турбіни поряд зі зниженням іiі внутрішнього відносного ККД. Припустиму вологість відпрацьованої пари звичайно обмежують значенням 8-9\%, що відповідає максимальному значенню початкової температури пари на рівні $88-90{ }^{\circ} \mathrm{C}$.

Таблиця 3. Розрахункові параметри бінарної ГеоТЕС залежно від температури випаровування робочого тіла

Table 3. Calculated parameters of binary GeoTPP depending on the evaporation temperature of the working fluid

\begin{tabular}{|c|c|c|c|c|c|c|}
\hline \multicolumn{2}{|c|}{ Вхід у турбіну } & \multirow{2}{*}{$\begin{array}{c}\text { Температура } \\
\text { флюїду } \\
\text { на виході } \\
\end{array}$} & \multirow{2}{*}{$\begin{array}{c}\text { Електрична } \\
\text { потужність } \\
\text { нетто } \\
\end{array}$} & \multirow{2}{*}{$\begin{array}{l}\text { Ккд } \\
\text { ПТУ }\end{array}$} & \multirow{2}{*}{$\begin{array}{c}\text { Питома } \\
\text { потужність } \\
\text { нетто } \\
\end{array}$} & \multirow{2}{*}{$\begin{array}{c}\text { Вологість } \\
\text { пари на } \\
\text { вихлопі }\end{array}$} \\
\hline $\begin{array}{c}\text { Tемпера } \\
\text { тура }\end{array}$ & Тиск & & & & & \\
\hline${ }^{\circ} \mathrm{C}$ & МПа & ${ }^{\circ} \mathrm{C}$ & кВт & $\%$ & кВт/(кг/с) & $\%$ \\
\hline 88 & 3,104 & 58,816 & 1841,161 & 8,759 & 28,326 & 7,96 \\
\hline 89 & 3,169 & 58,741 & 1860,273 & 8,841 & 28,620 & 8,39 \\
\hline 90 & 3,234 & 58,562 & 1881,293 & 8,920 & 28,943 & 8,86 \\
\hline
\end{tabular}


Технологічна схема ГеоТЕС з редукуванням тиску флюїду

Спрощену схему ГеоТЕС з редукуванням тиску флюїду наведено на рис. 3.

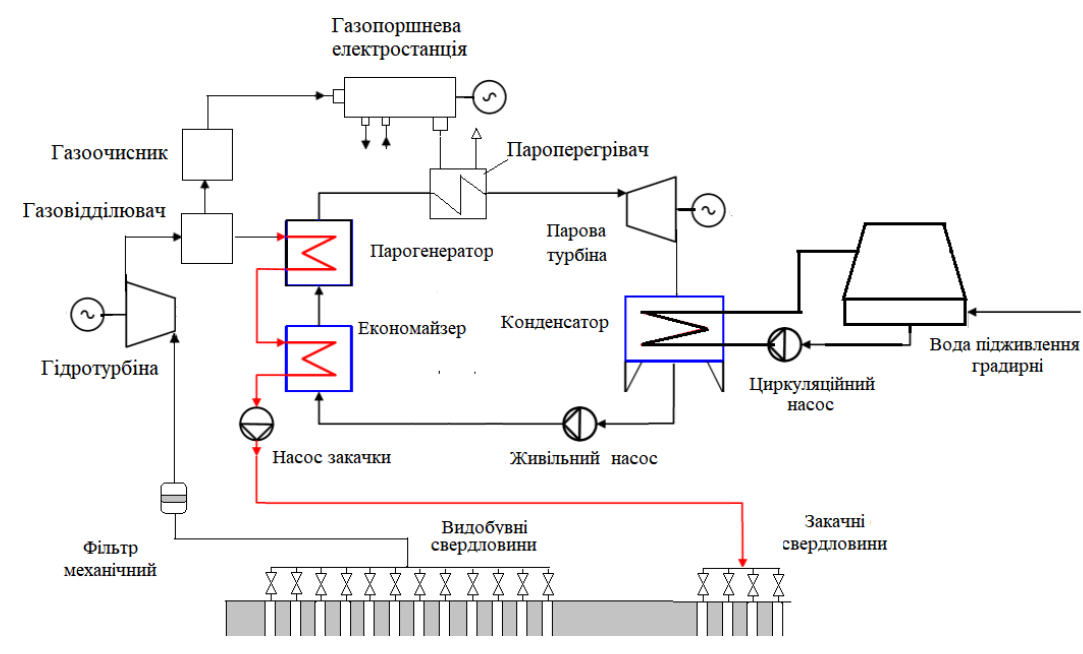

Рис. 3. Спрощена схема ГеоТЕС з редукуванням тиску

Fig. 3. Simplified geothermal circuit with pressure reduction

Флюїд 3 високим надлишковим тиском подається на гідротурбіну ковшового типу (турбіна Пелтона), де його тиск знижується до тиску насичення. Надалі здійснюється видалення 3 нього розчиненого метану в газовідділювачі. Частково знегазований флюїд подається в геотермальний теплообмінник, де віддає теплоту робочому тілу паротурбінного циклу, після чого насосом закачування нагнітається у пласт. Одержаний горючий газ після очищення подається на газопоршневу когенераційну установку для виробництва електричної й теплової енергії. Частина теплової енергії, що міститься у високотемпературних вихлопних газах газопоршневої установки, може використовуватися для перегріву пари робочого тіла в пароперегрівнику. Решта теплової енергії 3 систем охолодження сорочки циліндрів та другого ступеня, використовується для теплопостачання станції та/або у зовнішніх споживачів.

\section{Тепловий розрахунок ковшової} гідротурбіни Пелтона поданий у табл. 5 . Наведене у таблиці значення ККД турбіни прийнято згідно $з$ даними [5]. Зовнішній вигляд гідротурбіни представлений на рис. $4, a$.

Таблиця 4. Розрахунок гідротурбіни Пелтона

Table 4. Calculation of Pellton hydro turbine

\begin{tabular}{|l|c|c|}
\hline \multicolumn{1}{|c|}{ Показник } & Розм. & Значення \\
\hline Масова витрата флюїду & т/год & 234,0 \\
\hline Температура флюїду на вході & ${ }^{\circ} \mathrm{C}$ & 137,3 \\
\hline Тиск флюїду на вході & бар & 148,8 \\
\hline Гідравлічний ККД гідротурбіни & & 0,85 \\
\hline Температура флюїду на виході & ${ }^{\circ} \mathrm{C}$ & 136,5 \\
\hline Ентальпія флюїду на виході & кДж/кг & 574,0 \\
\hline Густина флюїду на виході & кг/$/ \mathrm{M}^{3}$ & 929,0 \\
\hline ККД генератора & & 0,95 \\
\hline Потужність електрична & кВт & 859,3 \\
\hline
\end{tabular}




\section{Відділення та використання паливного}

газу. Видалення газоподібних вуглеводнів (метану), розчинених у пластовій воді, відбувається внаслідок зниження розчинності в міру падіння тиску. Згідно 3 даними [6] рівноважна концентрація розчиненого метану у воді $V_{\mathrm{CH}_{4}}\left(\mathrm{Hм}^{3} / \mathrm{M}^{3}\right)$ залежно від тиску води $\mathrm{p}$, бар, у діапазоні тисків 1-120 бар та температур 100$140{ }^{\circ} \mathrm{C}$ може бути описана апроксимаційною залежністю:

$$
V_{C H_{4}}=0,18+0,0157 p,\left[\mathrm{HM}^{3} / \mathrm{M}^{3}\right] .
$$

Виділення метану, розчиненого у флюїді, відбувається через зниження розчинності при падінні тиску нижче рівноважного значення $p_{o}$, яке відповідає вихідній концентрації метану $V_{o}$ у пластовій воді:

$$
p_{o}=63,7\left(V_{o}-0,18\right) .
$$

Для забезпечення ефективної роботи турбіни Пелтона без утворення парової фази важливо підтримувати тиск води $\mathrm{p}_{2}$ не нижчим, ніж тиск насичення $\mathrm{p}_{\mathrm{s}}$ при температурі води перед турбіною. Вихід метану з води після редукування тиску в турбіні Пелтона може бути визначений за формулою:

$$
\begin{gathered}
\Delta V_{C H_{4}}=V_{o}-\left(0,18+0,0157 p_{2}\right),\left[\mathrm{HM}^{3} / \mathrm{M}^{3}\right](7) \\
p_{o}>p_{2}>p_{s} .
\end{gathered}
$$

Результати розрахунку витрати метану, що може бути видаленим з води, подано у табл. 5. У цій же таблиці наведено дані серійної газопоршневої когенераційної установки (ГПУ) типу TCG 2016 V12C, що відповідає розрахунковому обсягу одержання метану. Зовнішній вигляд установки представлений на

\begin{tabular}{|c|c|c|}
\hline Показник & Розм. & Значення \\
\hline Вихідна концентрація метану у воді & $\mathrm{HM}^{3} / \mathrm{M}^{3}$ & 1,0 \\
\hline Рівноважний тиск & бар & 52,2 \\
\hline Тиск насичення & бар & 3,7 \\
\hline Залишкова концентрація метану & $\mathrm{HM}^{3} / \mathrm{M}^{3}$ & 0,23809 \\
\hline Питомий вихід метану з води & $\mathrm{HM}^{3} / \mathrm{M}^{3}$ & 0,76191 \\
\hline Розрахункова витрата метану & тис. нм $3 /$ год & 0,190478 \\
\hline Теплота згоряння паливного газу & Гкал/1000м ${ }^{3}$ & 7,5 \\
\hline Теплова потужність ГПУ за паливом & кВт & 1428,6 \\
\hline Тип ГПУ & - & TCG 2016 V12C \\
\hline ККД ГПУ & $\%$ & 42 \\
\hline Електрична потужність ГПУ & кВт & 600 \\
\hline Теплова потужність ГПУ, в т. ч.: & кВт & 693 \\
\hline - сорочки охолодження & кВт & 317 \\
\hline - інтеркулера 2 ст. & кВт & 39 \\
\hline - $\quad$ вихлопу (вихідна температура $120^{\circ} \mathrm{C}$ ) & кВт & 337 \\
\hline
\end{tabular}
рис. 4,6 .

Таблиця 5. Розрахунок системи вилучення та використання розчиненого метану

Table 5. Calculation of extraction and use of methane dissolved 


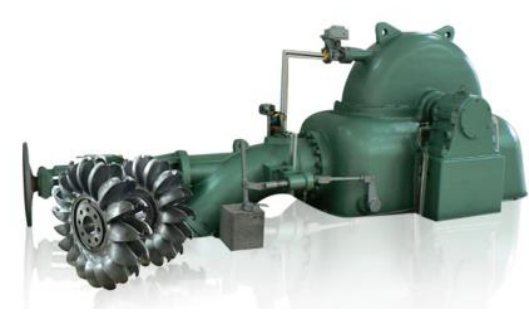

$a$

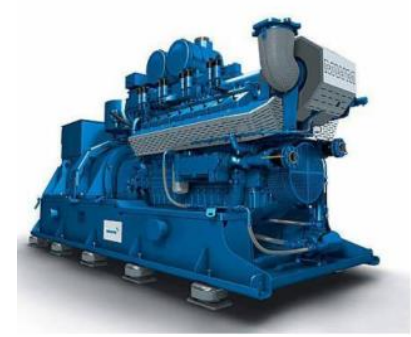

б

Рис. 4. Загальний вигляд обладнання ГеоТЕС з редукуванням тиску: $a$ - гідротурбіна Пелтона потужністю1000 кВт [11]; $\sigma$ - газопоршнева когенераційна ГПУ потужністю 600 кВт [12]

Fig. 4. General view of GeoTPP equipment with pressure reduction: a - Pelton hydroturbine with a capacity of $1000 \mathrm{~kW}$ [11]; b gas-piston cogeneration unit with a capacity of $600 \mathrm{~kW}[12]$

Узагальнені результати теплових і гідравлічних розрахунків варіантів технологічних схем ГеоТЕС на базі свердловини з АВПТ за розглянутими варіантами технологічних схем наведено у табл. 6, де прийняті такі позначення:

Варіант 1 (базовий) - використання бінарної ПТУ на органічному робочому тілі під повним тиском флюїду;
Варіант 2 - використання бінарної ПТУ на органічному робочому тілі 3 попереднім зниженням тиску флюїду без його дегазації;

Варіант 3 - використання бінарної ПТУ на органічному робочому тілі 3 попереднім зниженням тиску флюїду, виділенням розчиненого метану та його використанням для одержання електричної й теплової енергії за допомогою когенераційної ГПУ.

Таблиця 6. Технічні показники варіантів технологічних схем ГеоТЕС

Table 6. Technical indicators of variants of technological schemes of GeoTPP

\begin{tabular}{|c|c|c|c|c|}
\hline \multirow{2}{*}{ Показник } & \multirow{2}{*}{ Розм. } & \multicolumn{3}{|c|}{ Варіанти* } \\
\hline & & 1 & 2 & 3 \\
\hline Глибина свердловин & M & 3700 & 3700 & 3700 \\
\hline Температура у пласті & ${ }^{\circ} \mathrm{C}$ & 140 & 140 & 140 \\
\hline Вміст метану & $\mathrm{HM}^{3} / \mathrm{M}^{3}$ & 0 & 0 & 1 \\
\hline Об’ємна витрата флюїду & $\mathrm{M}^{3} /$ год & 250 & 250 & 250 \\
\hline Тиск на поверхні & бар & 148,7 & 148,7 & 148,7 \\
\hline Електрична потужність турбіни Пелтона & кВт & 0 & 859 & 859 \\
\hline Електрична потужність ГПУ & кВт & 0 & 0 & 600 \\
\hline Електрична потужність ПТУ & кВт & 2145 & 2145 & 2145 \\
\hline Електрична потужність насосу закачування & кВт & -200 & -1273 & -1284 \\
\hline Корисна електрична потужність ГеоТЕС & кBT & 1945 & 1731 & 2320 \\
\hline Теплова потужність ГеоТЕС & кBT & $\mathbf{0}$ & $\mathbf{0}$ & 690 \\
\hline
\end{tabular}

Висновки. Використання гідротермальних родовищ 3 АВПТ для виробництва електричної енергії стикається 3 проблемою вибору раціональних технологічних схем, типів i параметрів технологічного обладнання, які б забезпечили якомога повніше, безпечне та економічно прийнятне перетворення енергії геотермального флюїду. Високий тиск геотермального флюїду на поверхні та його можливі коливання при експлуатації родовища 3 АВПТ зумовлюють високу металоємність і велику вартість наземного технологічного й протиаварійного обладнання. У зв'язку з цим у роботі, поряд 3 базовим варіантом бінарної 
ГеоТЕС під повним тиском води, розглянуті альтернативні технології, що передбачають зниження вихідного тиску геотермальної води перед iї використанням у наземному обладнанні 3 його відновленням перед зворотним закачуванням у пласт. На прикладі родовища 3 АВПТ Мостицька (Закарпатська обл.) встановлено, що в разі зниження тиску за допомогою ковшової турбіни Пелтона корисна електрична потужність ГеоТЕС зменшується на $11 \%$, а робочий тиск і відповідно вартість наземної частини геотермального контуру - приблизно у 4-5 разів порівняно 3 ГеоТЕС під повним тиском геотермального флюїду. Можливість виділення 3 геотермальної води внаслідок зниження тиску розчиненого в ній метану та його використання у когенераційній газопоршневій установці дозволяє одержати 600 кВт електричної потужності, або $30 \%$ базового рівня та 690 кВт теплової потужності при концентрації розчиненого метану на рівні $1 \mathrm{нм}^{3} / \mathrm{M}^{3}$ води. При більшій концентрації метану додаткова потужність зростає пропорційно. Одержані результати можуть бути використані при проведенні техніко-економічних обгрунтувань проєктів спорудження ГеоТЕС на геотермальних родовищах 3 аномально високим пластовим тиском.

1. Аникиев К.А. Аномально высокие пластовые давления в нефтяных и газовых месторождениях. Л. Изд. «Недра». 1964. 168 с.

2. Ладыженский Н.P., Антипов В.И. Геологическое строение и газонефтеносность Советского Предкарпатья. Гостоптехиздат. Москва. $1961.266 \mathrm{c}$.

3. Geothermal Handbook: Planning and Financing Power Generation. The World Bank. Technical Report 002/12, 72828. Energy Sector Management Assistance Program (ESMAP) [Електронний ресурc]. URL: http://documents.worldbank.org/curated/ (en/396091468330258187/pdf/728280NWP0Box30k0TR 0020120Optimized.pdf (дата звернення: 01.06.2021)

4. Тройники штампованные из легированной стали ТУ 1469-005-04834179-2004. [Електронний pecypc]. URL: https://armtorg.ru/articles/item/2489/ (дата звернення: 01.06.2021)

5. Справочник конструктора гидротурбин / Л.Я. Бронштейн и др. Л. Изд. Машиностроение. 1971. 304 с.
6. Федоров В.А., Мильман О.О., Карышев А.К. и др. Тепловое испытание гидропаровой турбины в отопительной котельной. Теплоэнергетика. 2009. № 4. C. $61-63$.

7. Басок Б.И., Резакова Т.А., Чалаев Д.М. Перспективные когенерационные теплонасосные схемы геотермальной энергетики. Пром. теплотехника. 2006. T. 28 № 2. C. $35-40$.

8. Рузин Л.М. Разработка нефтяных месторождений с применением теплового воздействия на пласт: методические указания. Ухта: УГТУ. 2009. 39 с.

9. Алхасова Д.А., Алхасов Б.А. Использование среднепотенциальных геотермальных ресурсов для выработки электроэнергии. II Международная конференция «Возобновляемая энергетика: Проблемы и перспективы» Махачкала. 2010. С. 230-237. URL: http://www.ipgdncran.ru/files/file/BOOKS/2010_2_Conf. pdf (дата звернення: 04.06.2021).

10. Dotson C.R., Standing M.B. Pressure, Volume, Temperature and Solubility Relations for Natural GasWater Mixtures, Drill. \& Prod. Prac. API (1944) 173. URL: https://onepetro.org/APIDPP/proceedings-

abstract/API44/All-API44/API-44-173/52141

(дата звернення: 03.06.2021).

11. Гидрогенератор, водяная турбина pelton turbina 1 МВт. [Електронний pecypc]. URL: https://russian.alibaba.com/product-detail/hydrogenerator-water-pelton-turbine-turbina-1-mw60823032176.html?spm=a2700.8699010.normalList.5.2d a32634ld1KWm\&s=p (дата звернення: 04.06.2021).

12. TCG 2016 C. Газопоршневая когенерационная установка. Мощность: $400-800$ кВт эл. [Електронний ресурс]. URL:

https://www.roltrent.ru/upload/iblock/1fc/tcg2016.pdf (дата звернення: 04.06.2021).

\section{REFERENCES}

1. Anikiyev K.A. Anomalno vysokiye plastovyye davleniya $\mathrm{v}$ neftyanykh i gazovykh mestorozhdeniyakh. [Abnormally high reservoir pressures in oil and gas fields]. L. Nedra. 1964. 168 p. [in Russian].

2. Ladyzhenskiy N.R., Antipov V.I. Geologicheskoye stroyeniye i gazoneftenosnost Sovetskogo Predkarpatia. [Geological structure and oil and gas content of the Soviet Ciscarpathian region]. Gostoptekhizdat. Moskva. 1961. 266 p. [in Russian].

3. Geothermal Handbook: Planning and Financing Power Generation. The World Bank. Technical Report 002/12. 72828. Energy Sector Management Assistance Program (ESMAP). [Electronic resource]. URL: 
http://documents.worldbank.org/curated/ en/396091468330258187/pdf/728280NWP0Box30k0TR0 020120Optimized.pdf. [in English].

4. Troyniki shtampovannyye iz legirovannoy stali TU 1469-005-04834179-2004. [Tees stamped from stainless steel TC 1469-005-04834179-2004]. [Electronic resource]. URL: https://armtorg.ru/articles/item/2489/. (Applying date: 01.06.2021). [in Russian].

5. Bponshteyn L.Ya., German A.H., Goldin V.E. et al. Spravochnik konstruktora gidroturbin. [Handbook of the designer of hydraulic turbines ] L. Izd. Mashinostroyeniye. 1971. 304 p. [in Russian].

6. Fedorov V.A., Milman O.O., Karyshev A.K. et al. Teplovoye ispytaniye gidroparovoy turbiny $\mathrm{v}$ otopitelnoy kotelnoy. [Thermal test of a hydro-steam turbine in a heating boiler room]. Teploenergetika. 2009. No. 4. Pp. 61-63.

URL: http://www.turboconkaluga.ru/science2.shtml [in Russian].

7. Basok B.I., Rezakova T.A., Chalayev D.M. Perspektivnyye kogeneratsionnyye teplonasosnyye skhemy geotermalnoy energetiki. [Prospective cogeneration heat pump schemes for geothermal energy]. Prom. teplotekhnika. 2006. T. 28. No. 2. Pp. 35-40. URL: 06-Basok_Rezaova_tepl_skhemy_GeoTES.pdf [in Russian].

8. Ruzin L.M. Razrabotka neftyanykh mestorozhdeniy s primeneniyem teplovogo vozdeystviya na plast: metodicheskiye ukazaniya. [Development of oil fields using thermal impact on the reservoir: guidelines]. Ukhta. UGTU. 2009. 39 p. [in Russian].
9. Alkhapova D.A., Alkhapov B.A. Ispolzovaniye prednepotentpialnykh geotermalnykh repurpov dlya vyrabotki elektroenergii. [Use of mid-potential geothermal resources for power generation]. II Mezhdunarodnaya konferentpiya «Vozobnovlyayemaya energetika: Problemy i perppektivy». Makhachkala. 2010. Pp. 230-237.

URL: http://www.ipgdncran.ru/files/file/BOOKS/2010_2 Conf.pdf. (Applying date: 04.06.2021). [in Russian].

10. Dotson C.R. and Standing. M.B. Pressure. Volume. Temperature and Solubility Relations for Natural Gas-Water Mixtures.Drill. \& Prod. Prac. API (1944) 173.

URL: https://onepetro.org/APIDPP/proceedingsabstract/API44/All-API44/API-44-173/52141. (Applying date: 03.06.2021). [in English].

11. Gidrogenerator, vodyanaya turbina pelton turbina $1 \mathrm{MVt}$. [Hydro generator, water turbine Pelton turbine 1 MW]. [Electronic resource]. URL: https://russian.alibaba.com/product-detail/hydro-

generator-water-pelton-turbine-turbina-1mw- 60823032176.html?spm=a2700.8699010.normalList. 5.2da32634ld1KWm\&s=p. (Applying date: 04.06.2021). [in Russian].

12. TCG 2016 C. Gazoporshnevaya kogeneratsionnaya ustanovka. Moshchnost: $400-800 \mathrm{kVt}$ el. [Gas piston cogeneration unit. Power: $400-800 \mathrm{~kW}$ el]. [Electronic resource].URL: https://www.roltrent.ru/upload/iblock/1fc/tcg20 16.pdf (Applying date: 04.06.2021) [in Russian]. 